\title{
Literatur Review: Efektifitas Kompres Dinginterhadap Penurunan Intensitas Nyeri Pada Pasien Fraktur Tertutup
}

\author{
Nur Khasanah ${ }^{1^{*}}$, Tri Sakti Wirotomo ${ }^{2}$,Siti Rofiqoh ${ }^{3}$ \\ 1,2,3Program Studi Diploma Tiga Keperawatan, Fakultas Ilmu KesehatanUniversitas \\ Muhammadiyah Pekajangan Pekalongan, Indonesia \\ *email:nurkhasanah120499@gmail.com
}

\begin{abstract}
Fractures cause physiological disturbances, one of which is pain. Pain in fracture patients is caused by muscle spasms. Cold compression is the easiest method to reduce pain. This study identifies cold compresses' effect in reducing closed fracture patients by finding research articles from Google Scholar. Keywords for the search include "closed fracture", "pain intensity", and "cold compress", published in 2011-2020. Three articles were analyzed. The results showed that 57 total respondents were male (68.09\%) and female (31.91\%). Before the intervention was 6.72 , pain intensity dropped to 3.50 after the intervention with a p-value $<0.01$. This Literature Review concludes that cold compress therapy is effective in reducing pain among closed fracture patients. Nurses are expected to apply cold compress therapy as an intervention to reduce pain in fracture patients.
\end{abstract}

Keywords: cold compress; pain intensity; closed fracture;

\section{Abstrak}

Fraktur merupakan ancaman potensial maupun aktual terhadap integritas seseorang, sehingga akan mengalami gangguan fisiologis salah satunya respon berupa nyeri. Nyeri pada pasien fraktur disebabkan karena spasme otot. Upaya menurunkan nyeri pada pasien fraktur tertutup dengan cara memberikan terapi kompres dingin. Tujuan dari penulisan ini untuk menggambarkan pengaruh pemberian kompres dingin terhadap nyeri pasien fraktur tertutup. Desain karya tulis ini berupa Literature Review dengan jumlah tiga artikel yang diambil dari laman google scholar dengan kata kunci "fraktur tertutup", "intensitas nyeri", dan "kompres dingin", terbit tahun 2011-2020. Hasil analisa karakteristik responden dari ketiga artikel menunjukkan jumlah responden 57 pasien, sebagian besar laki-laki $(68,09 \%)$ sedangkan perempuan (31,91\%). Nilai rata-rata nyeri sebelum intervensi 6,72 setelah intervensi 3,50 dengan $p$-value 0,000 . Simpulan dari Literature Review ini adalah terapi kompres dingin efektif dalam menurunkan tingkat nyeri pasien fraktur tertutup. Saran bagi perawat diharapkan dapat menerapkan terapi kompres dingin sebagai salah satu intervensi untuk menurunkan nyeri pasien fraktur.

Kata kunci:kompres dingin; intensitas nyeri; fraktur tertutup;

\section{Pendahuluan}

Fraktur adalah hilangnya gangguan kontinuitas tulang, tulang rawan, baik yang bersifat total maupun sebagian. Secara umum, fraktur adalah patah tulang yang dapat di sebabkan oleh trauma atau tenaga fisik. Kekuatan dan sudut fisik, keadaan pada tulang itu sendiri, serta jaringan lunak di sekitar tulang akanmenentukan apakah fraktur yang terjadi lengkap atau tidak lengkap ${ }^{[9]}$. Keluhan yang sering di temukan pada fraktur adalah nyeri ${ }^{[10]}$.

Berdasarkan data yang diperoleh dari World Health Organization (WHO) mencatat pada tahun 2011 terdapat lebih dari 5,6 juta orang meninggal di karenakan insiden 


\section{Prosiding Seminar Nasional Kesehatan Lembaga Penelitian dan Pengabdian Masyarakat Universitas Muhammadiyah Pekajangan Pekalongan}

mengalami kecelakaan dan sekitar 1,3 orang mengalami kecacatan fisik. Kecelakaan memiliki prevelensi yang cukup tinggi yaitu insiden fraktur ekstermitas bawah sekitar $40 \%{ }^{[5]}$.fraktur di Indonesia menjadi penyebab kematian terbesar ketigan dibawah penyakit jantung koroner dantuberculosis. Menurut hasil data riset kesehatan dasar (Rikesdas) pada tahun 2011, di Indonesia terjadi fraktur di sebab kan oleh cidera seperti terjatuh, kecelakaan lalu lintas dan trauma tajam atau tumpul. Riset kesehatan dasar (2011) menemukan sebanyak 45.987 peristiwa terjatuh yang mengalami fraktur sebanyak 20.829 kasus dan yang mengalami fraktur sebanyak 1.770 orang $(8,5 \%)$, dari 14.127 trauma benda tajam ataupun tumpul, yang mengalami fraktur sebanyak 236 orang (1,7\%). Dan berdasarkan Kepolisian Republik Indonesia (POLRI) mencatat data sebanyak 23.385 orang tewas akibat kecelakaan lalu lintas selama tahun 2013.

Berdasarkan penelitian fraktur merupakan suatu ancaman potensial maupun aktual terhadap intensitas seseorang, sehingga dapat mengalami gangguan fisiologi maupun psikologis yang menimbulkan respon berupa nyeri.Nyeri tersebut merupakan keadaan subyek dimana seseorang memperlihatkan ketidak nyamanan secara verbal maupun non verbal ${ }^{[9]}$.

Nyeri murupakan gejala yang paling sering di temukan pada gangguan muskulokelatal.Serta nyeri pada penderita fraktur bersifat tajam dan menusuk. Nyeri tajam juga dapat di timbulkan oleh infeksi tulang mengakibatkan spasme otot atau penekanan pada syaraf sensoris ${ }^{[9]}$.

Berikut ini rasa nyaman merupakan salah satu kebutuhan dasar individu dan merupakan tujuan di berikan nya asuhan keperawatan pada seseorang di rumah sakit. Nyeri tidak lagi dapat di pandang kondisi alam dari cidera atau trauma yang akan berkurang secara bertahap seiring dengan waktu, nyeri tak mereda dapat menyebabkan komplikasi, peningkatan lama rawat inap di rumah sakit dan distress ${ }^{[10]}$. Berikut ini salah satu menajemen non farrmakologi untuk menurunkan nyeri yang di rasakan dengan melakukan kompres dingin. Dalam pemberian kompres dingin di percayai dapat meningkatkan pelepasan endorphin yang memblok transmisi stimulus nyeri dan juga menstimulasi serabut saraf berdiameter besar A-Beta sehingga dapat menurunkan transmisi implus nyeri melalui serabut kecil A- Delta dan serbut saraf $C$. Tindakan kompres dingin selain efek yang menurunkan sensasi nyeri, kompres dinging juga dapat memberikan efek fisiologis seperti menurunkan respon inflamasi jaringan, menurunkan aliran darah dan dapat mengurangi edema, mengurangi rasa nyeri lokal.

Sejalan dengan hasil penelitian diatas menurut ${ }^{[13]}$ kompres dingin dapat menurunkan nyeri dapat merelaksasi otot dengan cara menurunkan prostaglandin, yang memperkuat sensitivitas reseptor nyeri dan subkutan lain pada tempat cedera dengan memperhambat proses inflamasi. ${ }^{[19]}$ menjelaskan bahwa cold compress diyakini bisa meningkatkan pelepasan endorphin yang mengeblok pengantaran rangsangan nyeri dan terstimulasinya serabut saraf A-Beta sehingga menurunkan pengantaran imflus melalui serabut saraf C dan A- Delta. Hasil penelitian [15] menunjukkan kompres dingin memberikan pengaruh yang cukup signifikan dalam menurunkan intensitas nyeri pada pasien fraktur.

Berdasarkan penelitian pada terapi kompres dingin, digunakan modalitas terapi yang dapat menyerap suhu jaringan sehingga terjadi penurunana suhu jaringan 


\section{Prosiding Seminar Nasional Kesehatan 2021 Lembaga Penelitian dan Pengabdian Masyarakat Universitas Muhammadiyah Pekajangan Pekalongan}

melewati mekanisme konduksi. Efek pendinginan yang digunakan tergantung jenis aplikasi terapi dingin, lama terapi dan konduktivitas.Pada dasarnya agar terapi efektif, penurunan suhu harus dilakukan pada jangka waktu yang cukup.Inti dari terapi dingi adalah menyerap kalori area lokasi pada cidera sehingga terjadi penurunan suhu.terkait dengan hal tersebut, jenis terapi dengan terapi es basah lebuh efektif menurunkan suhu di bandingkan es dalam kemasan mengingat pada kondisi ini lebih banyak kalori tubuh yang di gunakan untuk mencairkan es.Semakin lama waktu terapi, penetrasi semakin dalam. Pada umumnya terapi dingin pada suhu $35^{\circ} \mathrm{C}$ selama 10 menit dapat memengaruhi suhu hingga $4 \mathrm{~cm}$ di bawah kulit. Jaringa otot kandungan air yang tinggi merupakan konduktor yang baik sedangkan jaringan lemak merupakan isolator suhu sehingga menghambat penetrasi dingin.

Terapi kompres dingin dapat dipakai dalam beberapa bentuk seperti penggunaan es dan cold batbs.Kompres dingin dapat mengurangi suhu pada daerah yang sakit, membatasi aliran darah dan mencegah cairan masuk ke jaringan yang berada di sekitar luka. Hal ini akan mengurangi nyeri dan pembengkakan. Kompres dingin dapat mengurangi sensitivitas dari akhiran syaraf yang berakibat terjadinya peningkatan ambang batas rasa nyeri. Secara fisiologis, Pada 15 menit pertama pemberian kompres dingin suhu $10{ }^{\circ} \mathrm{C}$ terjadi vasokontriksi arteriola dan venula secara local. Vasokontriksi ini disebabkan oleh aksi reflek dari otot polos yang timbul akibat stimulus system saraf otonom dan pelepasan epinefrin dan norepinefrin. Walaupun demikian, apabila dingin tersebut terus di berikan selama 15-30 menit akan timbul fase vasodilatasi yang terjadi intermien selama 4-6 menit. Periode ini di kenal sebagai respons hunting. Respons hunting terjadi untuk mencegah terjadinya kerusakan jaringan akibat anoksia jaringa.

\section{Literatur Review}

Literature Review adalah suatu metoda penulisan ilmiah dengan menggunakan cara mengkomplikasi, mengklasifikasi, dan mengevaluasi hasil penelitian yang telah ditulis oleh peniliti lain pada topik tertentu. Literature Review adalah metode penulisan yang mengkaji secara kritis pengetahuan, gagasan atau temuan yang ada dalam tubuh literature berorientasi akademik, serta merumuskan kontribusi teoritis dan metodologisnya untuk topik tertentu (Cooper \& Taylor diambil dalam Farisi, 2010 di ambil ${ }^{[8]}$.Dalam karya ilmiah ini penulis melakukan Literature Review sejumlah 3 artikel hasil penelitian.

\section{Metode}

Dalam penelitian karya tulis ilmiah ini menggunakan metode pengumpulan data yang di lakukan dengan mencari 3 artikel penelitian dengan topik efektifitas kompres dingin terhadap penurunan intensitas nyeri pada pasien fraktur tertutup dengan menggunakan pencarian google scholar atau cendekia dengan kata kunci kompres dingin, intensitas nyeri, fraktur tertutup. Menggunakan tahun penerbit minimal 2011, kemudian menganalisis dari 3 artikel tersebut menunjukkan ada penurunan tingkat nyeri pada pasien fraktur fraktur tertutup dengam menggunakan terapi kompres dingin. 


\section{Prosiding Seminar Nasional Kesehatan 2021 Lembaga Penelitian dan Pengabdian Masyarakat Universitas Muhammadiyah Pekajangan Pekalongan}

\section{Hasil dan Pembahasan}

\section{Hasil}

Hasil Literature Review dari 3 artikel pada penulisan ini menampilkan Distribusi Karakteristik responden Berdasarkan Jenis Kelamin dan menampilkan intensitas nyeri pada klien sebelum dan sesudah di lakukan kompres dingin. Hasil distribusi klien dapat di lihat pada tabel 4.1 dibawah ini.

Tabel 4.1 Distribusi Karakteristik responden Berdasarkan Jenis Kelamin

\begin{tabular}{ccccccccc}
\hline Karakteristik & \multicolumn{2}{c}{ Artikel 1 $(\mathrm{n}=30)$} & \multicolumn{2}{c}{ Artikel 2 $(\mathrm{n}=15)$} & Artikel 3 $(\mathrm{n}=12)$ & \multicolumn{2}{c}{$\begin{array}{c}\text { Total } \\
(\mathrm{n}=57)\end{array}$} \\
\cline { 2 - 9 } & $\mathrm{F}$ & $\%$ & $\mathrm{~F}$ & $\%$ & $\mathrm{~F}$ & $\%$ & $\mathrm{n}$ & $\%$ \\
\hline Laki - laki & 19 & 63,3 & 15 & 100 & 8 & 66,7 & 32 & 68,09 \\
\hline Perempuan & 11 & 36,7 & 0 & 0 & 4 & 33,3 & 15 & 31,91 \\
\hline
\end{tabular}

Berdasarkan Tabel 4.1distribusi responden berdasarkan jenis kelamin, di ketahui bahwa dari responden laki - laki di dapatkan dari artikel 1 ada 19 responden (63,3\%), artikel 2 ada 15 responden (100\%) dan artikel ke 3 ada 8 responden (66,7\%). Serta dari respnden perempuan di dapatkan dari artikel 1 ada 11 responden $(36,7 \%)$, artikel 2 tidak ada responden perempuan dan artikel 3 ada 4 responden (33,3\%). Jadi sebagian besar responden yang berjenis kelamin laki - laki lebih banyak sejumblah 32 responden $(68,09 \%)$ sedangkan responden perempuan sejumblah 15 responden $(31,91 \%)$.

Tabel 4.2Distribusi Tingkat Intensitas Nyeri berdasarkan Responden sebelum dan sesudah di berikan terapi kompres dingin.

\begin{tabular}{llll}
\hline & \multicolumn{2}{l}{ Nilai Rata-RataP. Value } & \\
\cline { 2 - 3 } Artikel & $\begin{array}{l}\text { Sebelum di lakukan } \\
\text { kompres dingin }\end{array}$ & $\begin{array}{l}\text { Sesudah dilakukan } \\
\text { kompres dingin }\end{array}$ & \\
\hline $\begin{array}{l}\text { Artikel 1 } \\
\mathrm{n}=30\end{array}$ & 7,00 & 5,47 & 0,000 \\
\hline $\begin{array}{l}\text { Artikel 2 } \\
\mathrm{n}=15\end{array}$ & 6,40 & 3,53 & 0,000 \\
\hline $\begin{array}{l}\text { Artikel 3 } \\
\mathrm{n}=12\end{array}$ & 5,83 & 2,83 & 0,000 \\
\hline $\begin{array}{l}\text { Total } \\
\mathrm{n}=57\end{array}$ & 6,72 & 3,50 & 0,000 \\
\hline
\end{tabular}

Berdasarkan tabel 4.2 menunjukkan bahwa rata - rata intensitas nyeri Responden sebelum dan sesudah diberikan terapi kompres dingin mengalami penurunan. Pada artikel 1 dari 7,00 menjadi 5,47. Pada artikel 2 dari 6,40 menjadi 3,53 pada artikel 3dari 5,83 menjadi 2,83 rata- rata nyeri responden. Berdasarkan tabel dapat disimpulkan bahwa total rata- rata nyeri responden sebelum dilakukan kompres dingin 6,72 menjadi 3,50 Dari ketiga artikel menunjukkan $p$-value 0,000 . Sehingga dapat disimpulkan bahwa terapi kompres dingin efektif untuk menurunkan nyeri pada pasien fraktur tertutup. 


\section{Prosiding Seminar Nasional Kesehatan 2021 Lembaga Penelitian dan Pengabdian Masyarakat Universitas Muhammadiyah Pekajangan Pekalongan}

\section{Pembahasan}

Hasil Literature Review pada tabel 3.1 menunjukan bahwa dari 3 artikel berdasarkan jenis kelamin, sebanyak 57 responden. Dapat di ketahui responden jenis kelamin laki - laki sebanyak 32 responden $(56,14 \%)$ dan perempuan sebanyak 15 responden (26,36\%). Berdasarkan responden dari 3 artikel diketahui jumblah responden laki-laki lebih banyak dibandingkan perempuan, artikel 1 laki - laki ada 19 responden, perempuan 11 responden, artikel 2 laki - laki 15 responden dan artikel 3 laki - laki ada 8 responden. Hal tersebut dikarenakan laki - laki cenderung lebih aktif dalam melakukan aktivitas di bandingkan dengan perempuan, sehingga yang dapat mengalami fraktur lebih banyak laki - laki di bandingkan pada perempuan ${ }^{[12]}$.

Hasil Literature Review pada tabel 3.2 menunjukan bahwa rata - rata skala nyeri sbelum diberikan terapi kompres dingin pada artikel $1(7,00)$, artikel $2(6,40)$ dan artikel $3(5,83)$, maka nilai rata- rata skala nyeri 6,72 yang merupakan kategorik nyeri sedang. Nyeri merupakan sensasi ketidak nyamanan yang bersifat individual. Serta nyeri tidak lagi di pandang sebagai kondisi alami dari cidera ataupun trauma yang akan berkurang secara bertahap seiring waktu, karena nyeri tak mereda dapat menyebabkan komplikasi ${ }^{[10]}$. Fraktur merupakan istilah hilangnya kontinuitas tulang, tulang rawan, baik yang bersifat total maupun sebagian. Secara ringkas dan umum, fraktur adalah patah tulang yang disebabkan oleh trauma atau tenaga fisik. Kekuatan dan sudut fisik, keadaan tulang itu sendiri, serta jaringan lunak di sekitar tulang akan menentukan apakah fraktur yang terjadi lengkap atau tidak lengkap menurut ${ }^{[9]}$.Keluhan utama yang sering di temukan pada pasien fraktur adalah nyeri ${ }^{[10]}$. Dalam karya tulis ini menggunakan terapi kompres dingin, kompres dingin merupakan suatu metode dalam penggunaan suhu rendah setempat yang dapat menimbulkan beberapa efek fisiologis. Kompres dingin menggunakan suhu rendah $12^{\circ} \mathrm{C}$ selama $5-10$ menit dapat mengurangi kecepatan konduksi sinyal nyeri kesaraf ${ }^{[21]}$.menurut, ${ }^{[13]}$ kompres dingin dapat di lakukan di lokasi nyeri atau disisi tubuh yang berlawanan tetapi berhubungan dengan lokasi nyeri, hal ini memakan waktu 5-10 menit. Cryotherapy merupakan penggunaan es ( ice pack) dan air Es dalam pengobatan cidera dan modalitas pengobatan yang umumnya digunakan pengelolaan cidera, Es dapat mengurangi aktifitas metabolismedalam jaringan sehingga mencegah kerusakan jaringan sekunder dan mengurangi nyeri ke system saraf pusat ${ }^{[3]}$. Pada tindakan terapi dingin dapat memberikan efek fisiologis, serta menurunkan respon inflamasi jaringan, menurunkan aliran darah, dan mengurangi edema ${ }^{[3]}$.

Hasil review pada Tabel 3.2 menunjukkan bahwa rata - rata nyeri setelah di berikan terapi kompres dingin pada artikel $1(5,47)$, artikel $2(3,53)$ dan artikel 3 $(2,83)$, maka rata - rata setelah dilakukan kompres dingin 3,50 yaang merupakan kategorik nyeri ringan. Serta didapatkan nilai $p$-value dari ke 3 artikel tersebut adalah 0,000.Dapat di artikan bahwa dari tabel tersebut menunjukkan terdapat perbandingan yang signifikan rata - rata tingkat intensitas nyeri pada pasien fraktur tertutup. Hal ini karena terapi dingin dapat menimbulkan efek analgetik dengan memperlambat kecepatan hantaran saraf sehingga implus nyeri yang mencapai otak lebih sedikit.Kemudian kompres dingin bekerja dengan menstimulasi permukaan kulit untuk mengontrol nyeri, serta untuk mengurangi aliran darah dan aktifitas saraf di area yang 


\section{Prosiding Seminar Nasional Kesehatan Lembaga Penelitian dan Pengabdian Masyarakat Universitas Muhammadiyah Pekajangan Pekalongan}

bengkak, memar, atau radang. Dengan kompres dingin, aliran darah menuju daerah yang cidera akan melambat dan pembuluh darah akan menyempit. kemudian akan mempengaruhi implus yang di bawa oleh serabut taktil A-Beta dengan sentuhan, tekanan, getaran oleh tubuh pergerakan untuk lebih mendominasi sehingga "gerbang " akan menutup dan implus nyeri akan terhalangi untuk sementara waktu ${ }^{[7]}$. Kompres dingin dapat di gunakan untuk mengurangi rasa nyeri pembengkakan dan peradangan akibat cedera. Dalam penggunaan suhu rendah bisa merangsang penyempitan diameter pembuluh darah dan memperlambat aliran darah yang menuju ke lokasi cedera Ketika tubuh mengalami cedera tersebut akan mengalami peradangan akibat cedera ini biasanya hanya langsung dalam waktu singkat hingga tubuh pulih dari cidera. Akan tetapi mengurangi keluhan tersebut, bisa menggunakan terapi nonfarmakologi dengan kompres dingin ${ }^{[2]}$.

Sejalan dengan hasil penelitian diatas menurut ${ }^{[13]}$ kompres dingin dapat menurunkan nyeri dapat merelaksasi otot dengan cara menurunkan prostaglandin, yang memperkuat sensitivitas reseptor nyeri dan subkutan lain pada tempat cedera dengan memperhambat proses inflamasi. ${ }^{[19]}$ menjelaskan bahwa cold compress diyakini bisa meningkatkan pelepasan endorphin yang mengeblok pengantaran rangsangan nyeri dan terstimulasinya serabut saraf A-Beta sehingga menurunkan pengantaran imflus melalui serabut saraf C dan A- Delta. Hasil penelitian [15] menunjukkan kompres dingin memberikan pengaruh yang cukup signifikan dalam menurunkan intensitas nyeri pada pasien fraktur.

Dari ketiga jurnal yang saya jadikan acuan sebagai Literature Review memiliki kesamaan yang menjadi dasar penulisan laporan karya tulis ilmiah ini yaitu, samasama memiliki pengaruh atau efektif dalam menurunkan nyeri pada pasien fraktur, responden yang di gunakan dalam ketiga jurnal tersebut juga memiliki kesamaan yaitu yang mengalami fraktur tertutup, Dan sama-sama menggunakan terapi kompres dingin untuk menurunkan nyeri pada pasien fraktur. Intervensi yang di gunakan pada ketiga penelitian adalah intervensi terapi kompres dingin pada pasien fraktur, yang pada prinsipnya terapi ini bertujuan untuk memaksimalkan pengobatan dan meminimalkan rasa nyeri, sehingga dapat efektif dalam mengatasi nyeri pada pasien fraktur.

\section{Kesimpulan}

Fraktur merupakan istilah hilangnya kontinuitas tulang, tulang rawan, baik yang bersifat total maupun sebagian. Secara ringkas dan umum, fraktur adalah patah tulang yang di sebabkan oleh trauma atau tenaga fisik. Simpulan dari karya tulis ilmiah pertama yang di lakukan oleh Andi Nurchairiah,Yesi Hasneli, Ganis Indriati terdapat pengaruh terapi kompres dingin terhadap penurunan nyeri pada pasien fraktur tertutup di lakukan terhadap 30 responden menggunakan desain quasi eksperimen untuk mengungkapkan hubungan sebab akibat dengan cara melibatkan kelompok control di samping kelompok eksperimen. Pada jurnal penelitian kedua yang di lakukan oleh Devi Mediarti, Rosnani, Sosya Mona Seprianti terdapat pengaruh terapi kompres dingin terhadap penurunan nyeri pada pasien fraktur tertutup dengan melibatkan kelompok kontrol samping kelompok eksperimen penelitia eksperimen dengan desain one group pre test-post test. Penelitian ketiga yang di lakukan oleh Lenni Sastra, Lola 


\section{Prosiding Seminar Nasional Kesehatan 2021 Lembaga Penelitian dan Pengabdian Masyarakat Universitas Muhammadiyah Pekajangan Pekalongan}

Despitasari terdapat pengaruh terapi kompres dingin terhadap penurunan nyeri pada pasien fraktur tertutup dilakukan terhadap 12 responden menggunakan desain quasi eksperimen pre dan post test. Simpulan dari tiga artikel penelitian tersebut adalah terapi kompres dingin efektif dalam menurunkan nyeri pada pasien fraktur tertutup.

\section{Referensi}

[1] Amin Huda, N \& Hardhi Kusuma."Buku Asuhan Keperawatan Jilid 2 Diagnosis NANDA, Intervensi NIC, Kriteria Hasil NOC. Yogyakarta", (2015).

[2] Andi Nurchairiah1. "Efektifitas Kompres Dingin Terhadap Intensitas Nyeri PadaPasien Fraktur Tertutup Di Ruang Dahlia RSUD Arifin Achmad Universitas Riau",(2013).

https://scholar.google.co.id/scholar?hl=id\&as sdt=0\%2C5\&as vis=1\&q=efektifit as+kompres+dingin+terhadap+intensitas+nyeri+pada+pasien+fraktur+tertutup \&btnG $=\# d=$ gs qabs\&u=\%23p\%3DSK97i747INYJ

[3] Arofah, I, A. "Buku Fisioterapi Olahraga.Jakarta EGC",(2015).

[4] Chang, William. "Metodologi Penulisan IImiah.Jakarta" : Penerbit Erlangga, (2014).

[5] Depkes, RI"Sistem Kesehatan Nasional'Diperoleh tanggal 22 desembaer 2013dari repository.usu.as.id/bitsream/123456789/22361/5/chafter I.Pdf,(2011).

[6] Devi Mediarti, Rosnani \& Sosya, "Pengaruh Pemberian Kompres Dingin Terhadap Nyeri Pada Pasien Fraktur Ekstermitas Tertutup" Di IGD RSMH Palembang Tahun 2012, "Jurnal Kedokteran Dan Kesehatan Volume 2 No 3 Oktober 2015 : 253 $260 ",(2015)$.

[7] Elia Purnamasari. "Efektifitas Kompres Dingin Terhadap Penurunan Intensitas Nyeri Pada Pasien Fraktur" Di RSUD Ungaran Jurnal Ilmu Keprawatan Dan Kebidanan (JIKK),(2014) .

https://scholar.google.co.id/scholar?hl=id\&as sdt=0\%2C5\&as vis=1\&q=efektifit as+kompres+dingin+terhadap+penurunan+intensitas+nyeri+pada+pasien+frakt ur\&btnG $=\# d=g s$ qabs\&u=\%23p\%3D9sPeSyPQnIw]

[8] Faiqoh, Zamrotul: Skripsi: "Analisis Peletakkan Genetic Momen Sejarah Matematika dalam Aktifitas pembelajaran". Surabaya; UIN Sunah Ampel Surabaya, 2013.

[9] Helmi,Z. N. 'Buku Ajaran Gangguan Muskuloskleletal'. Jakarta. Salemba Medika,(2012).

[10] Helmi,Z. N. 'Buku Ajaran Gangguan Muskuloskleletal'. Jakarta. Salemba Medika,(2013).

[11] Irianto, Koes. 'Pelayanan Keluarga Berencana". Bandung :Alfabeta, (2014).

[12] Khotijah, S. 'Efektivitas kompres dingin terhadap penurunan intesitas nyeri pada pasien fraktur". Diperoleh tanggal 23 oktober 2013.Dari ,(2011).

http://repository.usu.ac.id.http://repository.usu.ac.id.

[13] Kozier, B, et all. "Fundamental Keperawatan Konsep, Proses, Dan Praktik( Edisi 7 Vol 2)". Jakarta: EGC,(2010).

[14] Manurung, N. "Buku Keperawatan Medikal Bedah".konsep Mind Mapping Dan NANDA NIC NOC Jilid 3. Jakarta,(2018). 


\section{Prosiding Seminar Nasional Kesehatan 2021 Lembaga Penelitian dan Pengabdian Masyarakat Universitas Muhammadiyah Pekajangan Pekalongan}

[15] Mujahidin, Palasa, R., \& Utami, S. N. "Pengaruh Kombinasi Kompres Dingin Dan Relaksasi Nafas Dalam Terhadap Penurunan Intensitas Nyeri Fraktur Di Wilayah Kabupaten Provinsi Sumatra Selatan Tahun 2017;; Jurnal Ilmiah Multi Science Kesehatan,8,37-50,(2018).

[16] Muttaqin,Arif\& Sari Kurmala. "Gangguan Gastrointestinal' : Aplikasi Asuhan Keprawatan Medical Bedah. Jakarta : Salemba Medika,(2011),

[17] Rahma . Meikal Record Rumah Sakit Dr Mohammad Hoesin Palembang,(2012).

[18] Rendi, M,C. \& Margareth TH. "Buku Asuhan Keperawatan Medikal Bedah Penyakit Dalam".Yogyakarta,(2019).

[19] Rosnani. 'Jurnal Kedokteran dan Kesehatan volum 2,nomer 3 oktokber 2015:253-260", (2012).

[20] Sastra, L.,\& Despitasari, L. 'Pengaruh Terapi Dingin Cryotherapy Terhadap Penurunan Nyeri Pada Fraktur Ekstermitas Tertutup. Jurnal Kesehatan Hesti Wira Sakti, 6(2),28-23", (2018).

[21] Shaik., M., Birmingham.,\&Grewal. Short term sensory and cutaneous vascular responses to cold water immersion in patients with distal radius fracture (pdf). SM Journal of Ortopedics,1-8,(2015).

[22] Tim Pokja SDKI DPP PPNI. 'Standar Diagnosis Keperawatan Indonesia Defisinisi dan Indikator Diagnostik. Jakarta: Dewan Pengurus PPNI",(2017).

[23] Wiarto Giri ."Nyeri Tulang dan sendi. Yogyakarta Gosyen Publishing", (2017).

[24] Zakiyah, Ana. Nyeri: "Konsep dan Penatalaksanaan Dalam Praktik Keperawatan Berbasis Bukti. Salemba Medika", (2015). 